\title{
ANTIMICROBIAL ACTIVITIES OF LANTANA CAMARA LINN.
}

\author{
GIRISH K*
}

Postgraduate Department of Microbiology, Maharani's Science College for Women, Mysuru - 570 005, Karnatka, India. Email: girishk77@yahoo.com

Received: 28 November 2016, Revised and Accepted: 09 December 2016

ABSTRACT

Herbal drugs are the potential sources of therapeutic aid for the treatment and prevention of number of ailments as recognized very early by Ayurveda, Unani, and traditional folk - medical practitioners. The rich biodiversity of plants makes them a treasure house for obtaining new and novel compounds either themselves as drugs or lead molecules for drugs with different mechanisms of action. Lantana camara L. belonging to the family Verbenaceae and universally known as wild or red sage is the most widespread species of the genus. It occurs in most parts of the world as an evergreen notorious weed species. It is also considered as an ornamental garden plant. It is widely used in different traditional medical practices for treating various health problems. Different parts of the plant are used in treating various human ailments. The plant extracts and essential oil of L. camara possess various bioactivities including antimicrobial activities. The therapeutic potential of the plant is due to the occurrence of many bioactive phytocompounds. In last decade, scientists and researchers around the globe have elaborately studied the chemical composition of the whole plant of $L$. camara as well as its biological activities. This article reviews the antimicrobial activities of L. camara.

Keywords: Antimicrobial activities, Essential oils, Nanoparticles, Lantana camara, Solvent extracts.

(c) 2017 The Authors. Published by Innovare Academic Sciences Pvt Ltd. This is an open access article under the CC BY license (http://creativecommons. org/licenses/by/4. 0/) DOI: http://dx.doi.org/10.22159/ajpcr.2017.v10i3.16378

\section{INTRODUCTION}

Resistance to antimicrobial agents is a major global health problem, and the number of emerging multi-drug resistant microbial strains is continuously increasing. This situation has prompted researchers to develop efficient new antimicrobial agents, and thus the exploration of natural products to discover new drug molecules is continuously going on $[1,2]$. Medicinal plants could be a good alternative source for antibiotics in use (against which microbes have developed resistance), as most of the medicinal plants are safe with little or no side effects, cost-effective and have the ability to affect a wide range of antibiotic resistant microorganisms [3]. Medicinal plants contain several different phytochemicals or secondary metabolites that may act individually, additively or in synergy to improve human health [4]. Down the ages, essential oils (EOs) and other extracts of plants have evoked interest as sources of natural antimicrobial agents [5]. According to the WHO medicinal plants would be the best source to obtain a variety of drugs [6]. Lantana camara is one of the plants known for having many medicinal uses in traditional system of medicine, used in many parts of the world to treat a wide variety of disorders [7]. L. camara whole plant and plant parts, viz., leaves, flowers, roots, fruits, and EOs have been thoroughly studied for their chemical compositions and bioactivities. The present review aims to document the antimicrobial properties of L. camara.

\section{LANTANA CAMARA}

The genus Lantana (Verbenaceae) as described by Linnaeus in 1753 contained seven species, six from South America and one from Ethiopia. Lantana from the Latin lento, to bend, probably derives from the ancient Latin name of the genus Viburnum. Lantana is mostly native to subtropical and tropical America, but a few taxa are indigenous to tropical Asia and Africa. It is a genus of about 150 species. L. camara Linn., commonly known as wild or red sage, is the most widespread species of this genus [8]. It is planted as an ornamental plant and is now a highly invasive weed in many parts of the world. L. camara is found at altitudes from sea level upto $2000 \mathrm{~m}$ and can thrive very well under rainfall ranging from 750 to $5000 \mathrm{~mm}$ per annum and it grows up to $3 \mathrm{~m}$ height. It is a woody straggling evergreen, aromatic wild shrub (Fig. 1). The stems and branches are sometimes thorny. The leaves are arranged in opposite pairs and are broadly oval, bright green, rough with short hairs, with finely toothed edges along with a number of veins giving a wrinkled appearance. Flower heads contain 20-40 flowers, usually $2.5 \mathrm{~cm}$ across; the color of flowers varies from white, cream or yellow to orange pink, purple and red with small rounded heads, often in two colors. The fruits are fleshy berries in clusters, shiny and globose in shape, green in color which on ripening turns to black. The root system is very strong with a main taproot and a mat of many shallow side roots. L. camara is known by different names in different languages in India, viz., Raimuniya (Hindi), Chaturangi and Vanacehdi (Sanskrit) and Kakke, Natahu and Unnigida (Kannada), etc. [7,9,10].

\section{Chemical constituents}

L. camara is a rich source of bioactive compounds, viz., flavones, isoflavones, flavonoids, anthocyanins, coumarins, lignans, catechins, isocatechins, alkaloids, tannin, saponins, and triterpenoids. The various bioactive molecules isolated from different parts of the plant and its EOs were reported, and these details of L. camara phytochemistry have been compiled by a few authors $[8,10]$.

\section{Medicinal uses}

In India, herbal medicines have been the basis of treatment and cure for various diseases in traditional methods practiced such as Ayurveda, Unani, and Siddha [11]. L. camara has been used as an herbal medicine since long back. All parts of this plant have been traditionally used for several ailments worldwide. The plant extracts have been used in folk medicine for the treatment of cold, headache, uterine hemorrhage, chicken pox, conjunctivitis, eye injuries, whooping cough, asthma, bronchitis, tumors, chicken pox, measles, ulcers, swellings, skin rashes, eczema, eruptions, high blood pressure, bilious fevers, catarrhal infections, tetanus, rheumatism, malaria, jaundice, fistula, and pustules. Further, used for the treatment of skin itches, leprosy, scabies, used as an expectorant and as an antiseptic for wounds. L. camara is considered to be antiseptic, antispasmodic, anti-inflammatory, antihypertensive, antipyretic, analgesic, hypolipidemic, carminative, and diaphoretic 


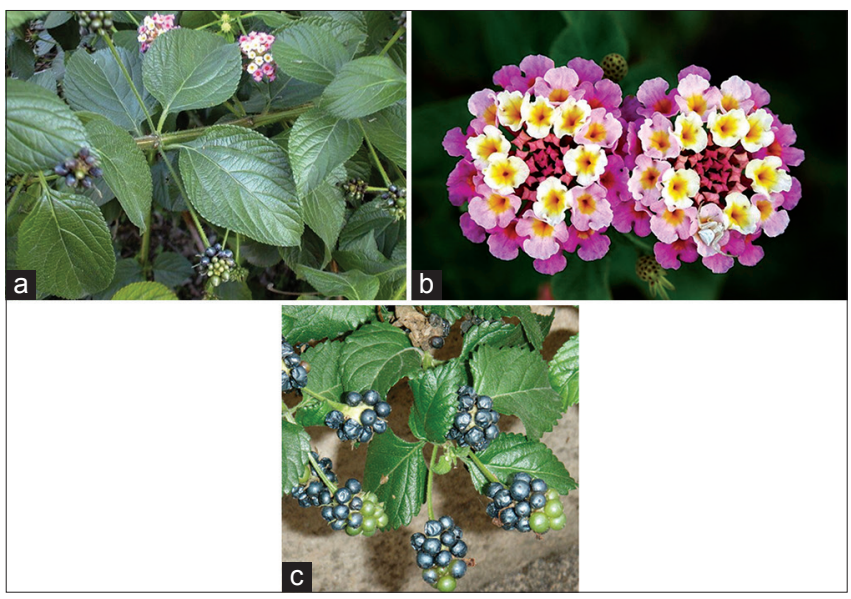

Fig. 1: Lantana camara (a) Leaves: Source: http://www.esc.nsw.gov. au/Lantana-camara, (b) Flowers: Source: https://en.wikipedia.org/ wiki/lantana_camara, (c) Fruits: Source: http://www.plant-worldseeds.com/lantana camara

agent. The extracts are reported to have antimicrobial, mosquito repellent, termiticidal, insecticidal, and larvicidal activities $[9,10,12]$.

\section{ANTIMICROBIAL ACTIVITIES}

Antibacterial, antifungal, antiprotozoal, antinematode, and antiviral activities of L. camara were reported. Solvent extracts, EOs, and nanoparticles of $L$. camara, all are reported to have antimicrobial activity. Lantadenes present in L. camara is believed to be responsible for almost all the biological activities. However, constituents such as 1,8-cineole, sabinene, and caryophyllene and other minor constituents, viz., E-nerolidol, bicyclogermacrene, and pinene identified in leaf EOs also found to be responsible for the biological activities. The presence of phenolics, anthocyanins, and proanthocyanidins in L. camara leaves could be responsible for the antibacterial properties of the L. camara [13]. The active principle of the extracts disrupts the permeability barrier of cell membrane structures and thus inhibits the bacterial growth [14]. EOs may interact with and affect the plasma membrane, interfering with respiratory chain activity and energy production [15].

\section{Antibacterial activity}

Different solvent extracts, EOs, and nanoparticles of L. camara have significant antibacterial activity (Table 1). Crude extract of L. camara root was found to be active against Staphylococcus aureus and Bacillus cereus [16]. Petroleum ether, benzene, chloroform, and methanol fractions of L. camara leaves were tested against Escherichia coli (ATCC 10536), Salmonella typhi (ATCC 686), S. aureus (ATCC 6538), and Pseudomonas aeruginosa (ATCC 25619). Chloroform and methanol extracts showed activity against all the bacteria tested, while petroleum ether fraction only against P. aeruginosa and benzene fraction only against $S$. typhi [17]. Antibacterial activity of extracts of $L$. camara root-bark was evaluated. Chloroform and methanolic extracts of L. camara were found to be more specific toward the Gram-positive strains, although Gramnegative $P$. aeruginosa was also inhibited by the methanol extract, while the aqueous extract was found to be inactive [18]. Dichloromethane and methanol $(1: 1, v / v)$ extract of $L$. camara exhibited significant antibacterial activity against E. coli (ATCC 10536) and P. aeruginosa (ATCC 9027) at both 1000 and $500 \mu \mathrm{g} / \mathrm{ml}$ concentrations [19]. Begum et al. [20] reported antimycobacterial activity of flavonoid, viz., linaroside and lantanoside and their acetyl derivative extracted from L. camara against Mycobacterium tuberculosis. These compounds exhibited $30 \%, 37 \%$ and $98 \%$ inhibition of the bacteria, respectively.

Extracts of root, stem, leaf, flower, and fruit of L. camara were screened for antibacterial activity. The leaf extract presented the highest antibiotic effect among all the parts tested, especially against $B$. cereus (zone of inhibition $13.0 \pm 0.0 \mathrm{~mm}$, minimum inhibitory concentration $[\mathrm{MIC}] /$ minimum bactericidal concentration $[\mathrm{MBC}] 9.4 \pm 4.4 \mathrm{mg} / \mathrm{ml}$ ) and S. typhi (zone of inhibition $13.5 \pm 2.1 \mathrm{~mm}, \mathrm{MIC} / \mathrm{MBC} 12.5 \pm 0.0 \mathrm{mg} / \mathrm{ml}$ ) [21]. Leaf and flower ethyl acetate extracts of L. camara with yellow, lavender, red, and white flowers exhibited considerable antibacterial activities against the bacteria E. coli (MTCC 901), P. aeruginosa (MTCC 429), Bacillus subtilis (MTCC 1429) and S. aureus (MTCC 96), where the value of zone of inhibition ranged from 10-21 and 9-15 mm, respectively [13]. Chloroform and methanol extracts of L. camara were screened against three strains of $M$. tuberculosis-H37Rv, the rifampicin-resistant TMC-331 and a non-resistant wild strain (28-25271). The methanol extract showed the highest activity against all the three strains used, with zones of inhibition of 18.0-22.5 mm and MIC values of $20 \mu \mathrm{g} / \mathrm{ml}$ for H37Rv and $15 \mu \mathrm{g} / \mathrm{ml}$ for both TMC-331 and wild stain. The MBC value for the methanol extract of L. camara was $30 \mu \mathrm{g} / \mathrm{ml}$ for the H37Rv, and $20 \mu \mathrm{g} / \mathrm{ml}$ for both the TMC-331 and wild strains [22]. Antibacterial efficacy of flavonoids (free and bound) and crude alkaloids of L. camara extracted from roots, stem, leaves, and flower was determined by disc diffusion assay against three bacteria: E. coli (MTCC 46), Proteus mirabilis (MTCC 1425), and S. aureus (MTCC 87). The susceptibility was in the order of P. mirabilis, S. aureus, and E. coli. The range of MIC of tested extracts was $0.039-0.625 \mathrm{mg} / \mathrm{ml}$ while $\mathrm{MBC}$ ranged from 0.078 to $1.25 \mathrm{mg} / \mathrm{ml}$ [3].

Antagonistic effect of water and organic solvent (ethanol of $50 \%$ and $100 \%$ ) extracts of $L$. camara was studied against 15 pathogenic strains of bacteria. Ethanol extracts showed antibacterial effect toward P. aeruginosa, Staphylococcus sp., Bacillus thuringiensis, B. subtilis, B. cereus, E. coli, S. aureus, P. mirabilis and water extract showed antibacterial effect toward P. aeruginosa, Staphylococcus sp., Citrobacter freundii, Proteus sp., B. subtilis, Enterobacter aerogenes, Salmonella paratyphi, S. aureus, and Shigella dysenteriae. Both extracts showed high antibacterial effect toward S. aureus, Staphylococcus sp., and $P$. aeruginosa [23]. Ethanolic extracts of $L$. camara leaves and roots were tested for antibacterial activity. The extracts exhibited activity against $S$. aureus, Proteus vulgaris, P. aeruginosa, Víbrio cholerae, E. coli and multiresistant strains of $E$. coli and $S$. aureus. Leaves ethanolic extract was more active against $P$. vulgaris and $V$. cholera with MIC of $128 \mu \mathrm{g} / \mathrm{ml}$ for both the strains; root extract was more effective against $P$. vulgaris and P. aeruginosa with MIC of 64 and $128 \mu \mathrm{g} / \mathrm{ml}$, respectively [24]. The antibacterial activity of the ethanol and aqueous extracts of the L. camara leaves was investigated against $B$. subtilis (MTCC 441), S. aureus (MTCC 3160), and P. aeruginosa (MTCC 4673) using agar diffusion technique. Results showed that only ethanolic extract was effective against all the bacteria with MIC between 25 to $125 \mathrm{mg} / \mathrm{ml}$ [25]. Alcoholic and aqueous extracts of L. camara showed significant activity against $E$. coli and moderate activity against other bacteria (P. aeruginosa, S. aureus and Bacillus sp.). Alcoholic extracts showed more antibacterial activity than water extracts. The MIC values ranged from 100 to $210 \mu \mathrm{g} / \mathrm{ml}$ [26].

Crude ethanolic and aqueous extract of L. camara were evaluated for antibacterial activity by the agar-well diffusion method against P. aeruginosa, Klebsiella pneumoniae, S. typhi, E. coli, Serratia marcescens, P. mirabilis, S. aureus, and Staphylococcus citreus. Ethanol extract presented the best results while aqueous extract showed moderate inhibition of the bacterial growth [27]. Chloroform extract of L. camara leaves showed good antibacterial activity as compared to standard drug ciprofloxacin against MTCC cultures, viz., Bacillus licheniformis 429, E. coli 40, P. vulgaris 426, P. aeruginosa 424, S. aureus 87 [28]. Antibacterial activity of petroleum ether, methanol, chloroform, and distilled water extracts of L. camara leaf, stem, and root was determined against E. coli, P. aeruginosa, S. aureus, and Staphylococcus saprophyticus. Methanol extract of stem and leaf parts showed activity against all the bacteria tested while root extract showed no activity on P. aeruginosa [29]. Antibacterial activity of petroleum ether, chloroform, ethanol, and aqueous extract of $L$. camara leaves were evaluated on $S$. aureus, B. subtilis, and E. coli. E. coli was equally sensitive to all the extracts while $S$. aureus was resistant to ethanolic extract. Petroleum 
Table 1: Antibacterial activity of Lantana camara

\begin{tabular}{|c|c|c|}
\hline Sl. No. & Bacteria (activity against) & References \\
\hline 1 & Acinetobacter baumannii & 37 \\
\hline 2 & Alcaligenes faecalis & 31 \\
\hline 3 & Arthrobacter protophormiae & 61 \\
\hline 4 & Bacillus subtilis; Bacillus cereus; Bacillus thurengiensis; Bacillus & $2,13,16,21,23,25,26,28,30,31,34,36,38,39,40,43$ \\
\hline & licheniformis; Bacillus sphaericus; Bacillus megaterium; Bacillus sp. & $44,46,47,54,55,58,59,62,64-68,71,72,73,75,76$ \\
\hline 5 & Citrobacter freundii & 23,34 \\
\hline 6 & Corynebacterium minutissimum & 35 \\
\hline 8 & Enterobacter aerogenes & 23,49 \\
\hline 9 & Enterococcus faecalis & 47 \\
\hline 10 & Escherichia coli & $\begin{array}{l}2,3,13,17,19,23,24,26-31,33,34,38,39,40,42,43,45, \\
46,47,49,50,51,53,54,55,60,62-67,69,71,73-80\end{array}$ \\
\hline 11 & Haemophilus influenzae & 37,42 \\
\hline 12 & Helicobacter pylori & 32 \\
\hline 13 & Klebsiella pneumoniae; Klebsiella sp. & $2,27,31,33,34,37,39,42,44,48,49,51,52,58,66,72$ \\
\hline 14 & Micrococcus luteus & $2,49,61,64$ \\
\hline 16 & Pantoea sp. & 34 \\
\hline 17 & Pasteurella multocida & 43 \\
\hline 18 & Proteus mirabilis; Proteus sp.; Proteus vulgaris & $3,23,24,27,28,34,39,40,41,42,50,59,60,74,79$ \\
\hline 19 & $\begin{array}{l}\text { Pseudomonas aeruginosa; Pseudomonas fluorescens; Pseudomonas sp.; } \\
\text { Pseudomonas syringae }\end{array}$ & $\begin{array}{l}13,15,17,18,19,23-29,31,33,34,35,37,38,44,47,50 \\
54,55,56,59,60,64,66,67,73,74,76,79\end{array}$ \\
\hline 20 & Rhodococcus rhodochrous & 61 \\
\hline 21 & $\begin{array}{l}\text { Salmonella typhi; Salmonella paratyphi; Salmonella setubal; Salmonella } \\
\text { typhimurium; Salmonella gallinarum }\end{array}$ & $\begin{array}{l}17,21,23,27,33,34,39,40,42,45,48,49,52,54,55,59, \\
69,71,72\end{array}$ \\
\hline 22 & Sarcina lutea & 67 \\
\hline 23 & Serratia marcescens; Serratia liquefaciens & 27,36 \\
\hline 24 & Shigella dysenteriae; Shigella flexnerii & $23,34,42$ \\
\hline 25 & $\begin{array}{l}\text { Staphylococcus aureus; Staphylococcus sp., Staphylococcus epidermidis; } \\
\text { Staphylococcus saprophyticus; Staphylococcus citreus }\end{array}$ & $\begin{array}{l}2,3,13,15,16,17,23--31,33,34,36,37,40,42--46,49 \\
50,51,53,54,55,58,61--67,69,71--74,76,78,79,80\end{array}$ \\
\hline 26 & $\begin{array}{l}\text { Streptococcus sp., Streptococcus agalactiae; Streptococcus pneumoniae; } \\
\text { Streptococcus pyogenes; Streptococcus sanguinis; Streptococcus faecalis }\end{array}$ & $31,34,37,38,45,52$ \\
\hline 27 & Víbrio cholerae; Vibrio parahaemolyticus Vibrio sp. & $24,31,34,35,48,60,72$ \\
\hline 28 & Xanthomonas axonopodis & 35 \\
\hline
\end{tabular}

ether and aqueous extracts did not produce zone of inhibition against B. subtilis [30]. The antimicrobial activity of crude ethanolic and acetone extracts of L. camara was determined against thirteen test bacteria such as E. coli (MTCC 443), B. subtilis (MTCC 1789), S. aureus, Streptococcus sp., P. aeruginosa, V. cholerae, Alcaligenes faecalis, B. cereus, K. pneumoniae (MTCC 2405), and Vibrio parahaemolyticus. Both the extracts exhibited good antibacterial activity against all the bacteria tested except $V$. parahaemolyticus. Alcoholic extract of leaves exhibited stronger antimicrobial activity in comparison with acetone extract [31]. Methanolic extract of L. camara leaves inhibited the growth of Helicobacter pylori with an inhibition zone of $20 \mathrm{~mm}$ [32].

Benzene, hexane, petroleum ether $\left(40-60^{\circ} \mathrm{C}\right)$, chloroform, ethanol, and ethyl acetate extracts of L. camara leaves were screened for antibacterial activity against $S$. aureus, S. typhi, P. aeruginosa, $K$. pneumoniae, and E. coli. All the extracts exhibited good antibacterial activity against all the tested bacteria. Sensitivity was in the order of $S$. aureus $>P$. aeruginosa $>E$. coli [33]. Antibacterial activities of methanolic extracts of L. camara stem and leaves were investigated. The clinical isolates - C. freundii, E. coli, K. pneumoniae, Pantoea sp., P. aeruginosa, S. typhi, Shigella flexneri, S. aureus, Streptococcus agalactiae, Staphylococcus epidermidis, $V$. cholerae and standard strains - B. cereus (ATCC 9144), E. coli (ATCC 25922), P. mirabilis (ATCC 35659) and S. aureus (ATCC 25923) were used for the study. L. camara extract exhibited significant antibacterial activity against all the bacteria tested except V. cholerae and E. coli (clinical isolate) [34]. The efficacy of aqueous and chloroform extracts of L. camara against four bacterial species, viz., Xanthomonas axonopodis, Pseudomonas syringae (Gram-negative bacteria) and Corynebacterium minutissimum, and Clostridium difficile (Gram-positive bacteria) were studied in vitro. Both extracts showed similar activities (moderate) against all the bacteria tested [35]. Ethyl acetate extracts of $L$. camara leaves and pods were evaluated for antibacterial activity against Bacillus circulans, B. subtilis, B. sphaericus, S. aureus, and Serratia liquefaciens. Ethyl acetate extracts of pods showed the highest antibacterial activity against tested clinical isolates followed by ethyl acetate extracts of leaves [36].

Gram-negative bacteria K. pneumoniae (RSKK 574), Haemophilus influenzae (ATCC 49766), P. aeruginosa (ATCC 10145), and Acinetobacter baumannii (RSKK 02026); Gram-positive bacteria Streptococcus pneumoniae (ATCC 19615), Streptococcus pyogenes (ATCC 13615), S. aureus (ATCC 25923), and S. epidermidis (ATCC 12228) were assessed for the determination of antibacterial activity. For antimycobacterial activity, the strains of Mycobacterium avium (ATCC 15769) and M. tuberculosis H37Rv (ATCC 27294) were used. L. camara (orange flowers, orange, and pink flowers) extracts exhibited inhibitory activities against Gram-positive bacteria and Gram-negative bacteria, with MICs ranging from 16 to $64 \mu \mathrm{g} / \mathrm{ml}$. The extracts also showed antimycobacterial activity against both $M$. tuberculosis and M. avium with MICs ranging between 8 and $32 \mu \mathrm{g} / \mathrm{ml}$ [37]. Petroleum ether and methanolic extracts of $L$. camara leaves were screened against E. coli, P. aeruginosa, B. subtilis, and Streptococcus faecalis. Both the solvent extracts showed good antibacterial activity against all the bacteria tested. The bacteria were more sensitive to petroleum ether extract than methanolic extract [38]. Aqueous extract of leaves and flower of L. camara showed positive activity against E. coli, S. aureus, P. vulgaris, B. subtilis and S. typhi. Aqueous extract of flower showed the highest activity against $E$. coli and $S$. aureus, i.e. $30 \mathrm{~mm}$ zone of inhibition whereas aqueous extract of leaves showed highest activity against $E$. coli $(26 \mathrm{~mm})$ and $P$. vulgaris $(25 \mathrm{~mm})$ [39]. Aqueous and alcoholic extracts of $L$. camara were evaluated for their in vitro antibacterial activity against $P$. mirabilis by serial dilution method. The reduction in $\mathrm{pH}$, ammonia concentration and urease activity in aqueous and alcoholic extracts (pH: 8.9250, ammonia: 5.32, $5.94 \mu \mathrm{g} / \mathrm{ml}$, urease: 
$0.010,0.011 \mathrm{IU} / \mathrm{ml}$, respectively) as compared to positive control (pH: 9.03, ammonia: $6.7 \mu \mathrm{g} / \mathrm{mL}$, urease: $0.013 \mathrm{IU} / \mathrm{ml}$ ) indicated antibacterial activity of L. camara extracts against P. mirabilis in broth culture [40].

The methanolic leaf extract was tested for its antibacterial activity against different human pathogenic bacteria E. coli, $H$. influenzae, K. pneumoniae, P. mirabilis, S. typhi, S. flexneri, and S. aureus. All the bacteria tested were inhibited at varying levels by the methanolic extract at different concentrations used such as $2,4,6,8$, and $10 \mathrm{mg} / \mathrm{ml}$. K. pneumoniae was highly susceptible, followed by $E$. coli and $H$. influenzae, while P. mirabilis was least susceptible [41]. The antibacterial activity of $L$. camara flower extracts (ethanol and methanol) against four bacterial strains: E. coli, S. aureus, Pasteurella multocida, and B. subtilis was assessed by disc diffusion method. The results showed that all the extracts of L. camara flowers possessed notable antibacterial activity against all the tested bacterial strains [42]. Methanol, ethanol and water extracts of $L$. camara leaves were evaluated against four bacterial isolates ( $S$. aureus, $P$. aeruginosa, $K$. pneumoniae, and $B$. subtilis). Methanol extract showed maximum antibacterial activity against $S$. aureus and $P$. aeruginosa and was also effective against other bacterial strains as compared to ethanol and aqueous extracts [43]. In vitro antibacterial activities of cold-ethanolic extracts of $L$. camara leaves were compared to the hot-ethanolic extracts of the same plant for antibacterial activity. The highest zone of inhibition was recorded against $S$. pyogenes $(28 \mathrm{~mm})$, while moderate zone of inhibition was recorded against S. aureus $(25 \mathrm{~mm})$ and E. coli $(23 \mathrm{~mm})$ and weak antibacterial activity was recorded against $S$. typhi $(18 \mathrm{~mm})$ with cold ethanolic extract. Hot extract recorded comparatively less zone of inhibition for all the bacteria tested. The cold extract was more effective compared to the hot extract [44].

Petroleum ether, methanol, ethyl acetate, and water extracts of L. camara leaves were screened against E. coli, S. aureus, and B. subtilis. Petroleum ether extract showed the highest antibacterial activity while methanol and ethyl acetate extracts showed moderate activity. All extracts showed maximum zone of inhibition at $200 \mu \mathrm{g} / \mathrm{ml}$ concentration [45]. Crude and column extracts of L. camara leaves and flowers were tested for antibacterial activity. The extracts showed activity against $E$. coli, P. aeruginosa, B. subtilis, and Enterococcus faecalis with 6.8-8.1 $\mathrm{mm}$ (crude) and 4.0-6.2 $\mathrm{mm}$ (column) zone of inhibition. The bioactive compound parthenin was isolated from the HPLC analysis of extracts [46]. Inhibitory effect of the solvent extracts (methanol, chloroform, diethyl ether and hot water) of L. camara roots against four different bacterial strains (S. typhi, S. paratyphi, K. pneumoniae, and V. cholerae) was studied. All the extracts inhibited bacterial growth at $5 \mathrm{mg} / \mathrm{ml}$ concentration except hot water extract which showed no activity against $K$. pneumoniae. Among all solvent extracts, the methanol extract showed the best inhibitory activity [47]. Methanol extract of L. camara fruit was assayed against six bacterial strains, viz., S. aureus (ATCC 6538), Micrococcus luteus (ATCC 10240), Salmonella setubal (ATCC 19196), E. aerogenes (ATCC 13048), K. pneumoniae (ATCC 1705), and E. coli (ATCC 5224). The extract showed good antibacterial activity against all the tested bacteria with inhibition zone ranging between 9 to $12.3 \mathrm{~mm}[48]$.

Antimicrobial activities of methanol, chloroform, acetone, petroleum ether and hexane extracts of $L$. camara seed was investigated against $S$. aureus, P. aeruginosa, $P$. vulgaris and E. coli. Methanolic extract showed maximum inhibition against $S$. aureus, $P$. aeruginosa and $E$. coli and no inhibition against $P$. vulgaris. Similarly, the acetone extract showed inhibition against $S$. aureus, $P$. vulgaris and lesser activity against $E$. coli. The other extracts had no antibacterial activity against any bacterial strains tested [49]. The antibacterial activities of leaf extract of L. camara alone or in combination with gentamicin or ceftriaxone were determined by in vitro study against E. coli (ATCC 25922), S. aureus (ATCC 25923) and fully characterized NDM-1 strains of $K$. pneumoniae. The results showed the inhibitory activity of extract against $E$. coli (3.5 mm), S. aureus ( $4 \mathrm{~mm})$, and NDM1 strain $(1.2 \mathrm{~mm})$. The synergistic effect was observed, of extract and gentamicin against E. coli $(5.5 \mathrm{~mm})$, of extract and ceftriaxone against $S$. aureus $(6.0 \mathrm{~mm})$. Notable effect was obtained with extract and gentamicin against NDM1 strain with $2.2 \mathrm{~mm}$ zone of inhibition [50]. Antimicrobial activity of hexane extract of $L$. camara leaves was evaluated against $S$. pneumoniae, S. typhi, and K. pneumoniae. The hexane extract showed antibacterial activity only against $S$. pneumoniae in all the concentrations tested [51]. Aqueous ethanol extract (3:1) of $L$. camara leaves showed good antibacterial activity against K. pneumonia (MTCC 1320) and V. parahaemolyticus (MTCC 451), moderate activity against $E$. coli (MTCC 443) and B. subtilis (MTCC 121), and no activity against Pseudomonas fluorescens (MTCC 2421) [52].

The antibacterial activities of L. camara leaf and root ethanol extracts alone or in association with aminoglycosides were determined against bacterial strains by microdilution test. The extracts exhibited inhibitory activity against multiresistant strains of $E$. coli and $S$. aureus. The MICs for all antibiotics tested decreased in the presence of the extracts. The results indicated the antibacterial activity of L. camara extracts and their potential in reducing the resistance of bacteria to aminoglycosides [53]. Ethyl acetate, methanol, acetone, and chloroform extracts of $L$. camara leaves were effective against both Gram-positive (S. aureus, B. subtilis, M. luteus) and Gram-negative (E. coli, K. pneumoniae) bacterial strains tested, but their efficacy varied. Gram-negative bacteria were more susceptible to all extracts compared to Gram-positive bacteria. Methanol extract had the highest inhibition activity against all the tested microbes when compared to any other solvent extracts tested [2]. Ethyl acetate extract of $L$. camara root bark showed effective antibacterial activity with zone of inhibition of 31,34, 40, 40 and $32 \mathrm{~mm}$ against E. coli, S. typhi, Pseudomonas sp., S. aureus, and B. subtilis, respectively [54]. Ethyl acetate and ethanol extract of $L$. camara flower possessed strong antibacterial effect against E. coli, S. typhi, Pseudomonas sp., S. aureus, and B. Subtilis. Ethyl acetate extract produced zone of inhibition 35, 34, 33, 32, and $32 \mathrm{~mm}$ against E. coli, S. typhi, B. Subtilis, Pseudomonas sp., $S$. aureus, respectively. The zone of inhibition for ethanol extract was found to be 34, 34, 30, 30 and $25 \mathrm{~mm}$ against S. typhi, S. aureus, E. coli, Pseudomonas sp. and B. subtilis, respectively [55].

EOs

The EO of L. camara exhibited a wide spectrum of antibacterial activities against seven bacteria screened. Highest inhibition was observed against $P$. aeruginosa [56]. Kasali et al. [57] reported considerable antibacterial activity of L. camara leaves EO against both Gram-positive and Gram-negative bacteria tested at $5 \mathrm{mg} / \mathrm{ml}$ concentration. EO of L. camara was evaluated for antibacterial activity and the oil completely inhibited the growth of Bacillus megaterium, S. aureus, Klebsiella sp., at 1600 ppm [58]. The EO of L. camara leaves was tested against 6 strains, using disc diffusion method. The oil showed moderate activity against B. subtilis ATCC 33923, S. typhi ATCC 2785, P. aeruginosa ATCC 27856, B. aureus ATCC 14579, and P. mirabilis ATCC 21784 [59]. L. camara EOs exhibited considerable antibacterial activity against $E$. coli (ATCC 25922), P. vulgaris (ATCC 13315), P. aeruginosa (ATCC 15442), and V. cholera (ATCC 15748) [60].

E0 of L. camara showed antibacterial activity by direct contact against Arthrobacter protophormiae, M. luteus, Rhodococcus rhodochrous and $S$. aureus with MBC of 50, 25, 12.5 and $200 \mu \mathrm{g} / \mathrm{ml}$, respectively [61]. The EO of L. camara was tested against E. coli, S. aureus and Bacillus sp. E. coli $(25 \mathrm{~mm})$ and $S$. aureus $(29 \mathrm{~mm})$ were more susceptible toward EO in comparison to the Bacillus sp. (19 mm). The MIC was 1.25, 1.0 and $1.75 \mu \mathrm{g} / \mathrm{ml}$ for E. coli, S. aureus and Bacillus sp., respectively [62]. EO of L. camara leaves was examined for antibacterial and modulatory activity against two multiresistant strains, $E$. coli from sputum and $S$. aureus from surgical wound. The results showed inhibition of $E$. coli (MIC $512 \mu \mathrm{g} / \mathrm{ml}$ ) and S. aureus (MIC $256 \mu \mathrm{g} / \mathrm{ml}$ ). The synergism of the EO on aminoglycosides was observed with a significant reduction of MICs (1250 to $5 \mu \mathrm{g} / \mathrm{mL}$ ) against E. coli [63]. Hydrosol of L. camara leaves obtained with waste of EO was studied for antibacterial activities. Gramnegative bacteria E. coli (MTCC 443), P. aeruginosa (MTCC 741) were resistant and Gram-positive bacteria B. cereus (MTCC 430), S. aureus 
(MTCC 87) and M. luteus (MTCC 106) were sensitive to leaf hydrosol [64]. Volatile oils from the leaves of L. camara showed moderate antibacterial activity against $E$. coli, $S$. aureus and B. subtilis [65]. The EO of L. camara exhibited significant antibacterial activity against E. coli, B. subtilis, $B$. cereus and $S$. aureus and moderate activity against $K$. pneumoniae and P. aeruginosa. Gram-positive bacteria were more sensitive than Gramnegative bacteria [66].

The antibacterial activity of EO of $L$. camara leaves was assessed against B. subtilis ATCC 6633, S. aureus ATCC 6538 and Sarcina lutea ATCC 934, E. coli ATCC 8739 and P. aeruginosa ATCC 9027. The EO showed activity against B. subtilis, S. aureus, E. coli and S. lutea at MICs values of $500,500,500$ and $<250 \mu \mathrm{g} / \mathrm{ml}$, respectively. It even showed activity against $P$. aeruginosa but at high concentration with MIC of $5000 \mu \mathrm{g} / \mathrm{ml}$ [67]. The EO of L. camara inhibited the growth of S. aureus and $P$. aeruginosa with MIC of 1 and $>1 \mathrm{mg} / \mathrm{l}$, respectively. The activity of the antibiotic amikacin was increased against S. aureus (by 29\%) and $P$. aeruginosa (by 65\%) in the presence of EO and the activity of gentamicin against $P$. aeruginosa by $21 \%$ [15]. The essential oil of flowers and leaves of $L$. camara species growing in Egypt exhibited in vitro antimicrobial activity against B. cereus (ATCC 33018) and B. subtilis (ATCC 6633) with MIC ranging between 1.25 to $5 \mathrm{mg} / \mathrm{ml}$ [68]. The essential oil of $L$. camara flowers exhibited antibacterial activity against S. aureus, Streptococcus sanguinis, E. coli, Salmonella typhimurium with MIC of $500 \mu \mathrm{g} / \mathrm{ml}$ [69]. EO from leaves of L. camara (EOLC) was evaluated against mycobacteria. The results revealed that the EO was not able to inhibit the growth of tested Mycobacterium sp., until $1250 \mathrm{mg} / \mathrm{ml}$ of EOLC [70]. L. camara leaf ethanolic fraction (EF) and EO demonstrated antibacterial activity against $S$. aureus, B. subtilis, E. coli, and Salmonella gallinarum. The MIC of EO ranged from 312.5 to $10,000 \mu \mathrm{g} / \mathrm{ml}$ and of EF from 1250 to $5000 \mu \mathrm{g} / \mathrm{ml}$. B. subtilis was the most sensitive organism inhibited at $312.5 \mu \mathrm{g} / \mathrm{ml}$ while $S$. gallinarum showed less sensitivity [71].

\section{Nanoparticles}

The antibacterial activity of silver nanoparticles (AgNPs) synthesized from the aqueous extract of $L$. camara fruits was examined against six pathogenic bacteria such as M. luteus ATCC 4698, B. subtilis MTCC 1133, S. aureus MTCC 96, V. cholerae ATCC 14035, K. pneumoniae MTCC 109, and $S$. typhi MTCC 733. The maximum activity was $26 \mathrm{~mm}$ zone of inhibition for B. subtilis and $22 \mathrm{~mm}$ zone of inhibition against $S$. typhi. AgNPs were found to be more effective against Grampositive bacteria than Gram-negative bacteria [72]. Biosynthesized AgNPs from aqueous extract of $L$. camara leaves showed significant antibacterial activity at 100, 200 and $300 \mu \mathrm{g} / \mathrm{ml}$ against B. Subtilis, S. aureus, E. coli and P. aeruginosa [73]. AgNP's of L. camara seed acetone extract had effective antibacterial activity against $S$. aureus, P. aeruginosa, P. vulgaris and E. coli in all concentrations tested [74]. Verma and Balasubramanian [75] immobilized the EO of L. camara on the nanocomposite polyacrylonite membrane and showed it to have exceptional antibacterial activity against $E$. coli and B. subtilis $(7-10 \mathrm{~mm}$ zone of inhibition). The synthesized AgNPs of L. camara leaf extract exhibited good antibacterial activity against E. coli, Pseudomonas spp., Bacillus spp., and Staphylococcus spp. The leaf extract itself acted as both reducing and stabilizing agent at once for desired nanoparticle synthesis [76]. The AgNPs synthesized by leaf extract of L. camara showed strong antibacterial activity against $E$. coli [77]. 80\% ethanolic extracts of $L$. camara leaves and copper oxide nanoparticles were mixed in different ratio to produce composites and then their antibacterial activity was assessed. The composites yielded a better result than the herbal particles or nanoparticles alone against the test organisms S. aureus (ATCC 11226) and E. coli (ATCC 6529), and the maximum activity was found to be around 30 and $33 \mathrm{~mm}$ zone of inhibition, respectively [78]. The AgNPs synthesized by aqueous extract of $L$. camara seed exhibited significant antibacterial activity against $S$. aureus, $P$. aeruginosa, $P$. vulgaris, and E. coli. Maximum zone of inhibition was absorbed against $P$. aeruginosa and minimum zone against $P$. vulgaris [79]. AgNPs of L. camara leaf extract showed very high antibacterial activity against $E$. coli and $S$. aureus at a very low concentration of $50 \mathrm{ppm}$ nanoparticles. Inhibition was by leakage due to cell wall rupturing [80].

\section{Antifungal activity}

Although the synthetic fungicides are effective in controlling the plant diseases, the undesirable attributes of their use demand alternative treatments that are less hazardous to humans and animals and less impact on the environment. Extracts isolated from plants provide promising alternative. Antifungal activities of L. camara have been reported. Experiments on mode of action suggested that the extracts lyse the cells and alter the membrane integrity by depleting the ergosterol content, which avoid the reoccurrence [81]. Different solvent extracts, EOs as well as nanoparticles of $L$. camara have great antifungal activity (Table 2). Crude extract of $L$. camara root was effective against Cladosporium sphaerospermum [16]. L. camara extract significantly inhibited the radial growth of Fusarium oxysporum f. sp. lini causing wilt of linseed at 30\% concentration and checked the wilt of linseed in wilt stil pots. Seed treatment with leaf powder drastically reduced the plant mortality even after 40 days of sowing [82]. Patel et al. [83] screened the antimicrobial activity of $L$. camara extract and reported antifungal activity against Aspergillus niger and Aspergillus awamori.

The methanol, diethyl ether, ethyl acetate, n-butanol, chloroform and aqueous extracts of $L$. camara leaves and flowers were screened against Trichophyton rubrum. Methanol extract showed maximum activity (98\% inhibition) followed by ethyl acetate extract (85\%), diethyl ether and n-butanol (80\%), chloroform (60\%) against T. rubrum at $100 \mu \mathrm{g} / \mathrm{ml}$, while aqueous extracts inhibited the growth of this fungus at the same concentration by $32-44 \%$. The activity of the methanolic extract was also determined against Microsporum canis, Microsporum gypseum, Trichophyton mentagrophytes, Trichophyton verrucosum, and Epidermophyton floccosum. Extract was very effective against all the tested fungi. The percent inhibition ranged from $50 \%$ to $80 \%$ [84]. Acetone extracts of different parts of $L$. camara were found to produce moderate to good antifungal activity against all phytopathogenic fungi (Penicillium janthinellum, Penicillium expansum, Aspergillus parasiticus, A. niger, Colletotrichum gloeosporioides, F oxysporum, Trichoderma harzianum, Phytophthora nicotiana, Pythium ultimum, and Rhizoctonia solani) studied. Leaf extracts were more active than seed or flower extracts [85]. Antifungal efficacy of flavonoids (free and bound) and crude alkaloids of L. camara extracted from roots, stem, leaves, and flower was determined by disc diffusion assay against Candida albicans (MTCC 183) and dermatophytic fungi T. mentagrophytes (MTCC 7687). Most susceptible fungus was C. albicans followed by T. mentagrophytes. The range of MIC of tested extracts was $0.039-0.625 \mathrm{mg} / \mathrm{ml}$ while minimum fungicidal concentration ranged from 0.078 to $1.25 \mathrm{mg} / \mathrm{ml}$ [3]. Sharma and Kumar [86] reported antifungal potential of flavonoids of L. camara (flower) against $F$. oxysporum (MTCC 7678). Observations revealed that the free flavonoids were more effective than the bound flavonoids and alkaloids of the plant. Antifungal activity of ethanol and hot water extracts of L. camara was screened against wood destroying white and brown rot fungi (Trametes versicolor, Oligoporus placenta). Both extracts exhibited efficient antifungal activity against white and brown rot fungi, however, ethanol extract was highly potential at very low concentration $(0.01 \%)$ [87].

Methanolic extracts from different parts of L. camara were evaluated for potential antimicrobial activity against Alternaria alternata (MTCC 1362), A. niger (MTCC 2723), Macrophomina phaseolina (MTCC 2165), and $R$. solani (MTCC 4633). L. camara extract showed highest activity $(10 \mathrm{~mm})$ against $A$. alternata and M. phaseolina, lowest activity against R. solani and no activity against $A$. niger [88]. Aqueous extract of leaf and seed of L. camara showed some potentiality to inhibit the growth of a few seed borne fungi, Phomopsis vexans, F. oxysporum, Aspergillus flavus, A. niger, Curvularia lunata and Penicillium sp., (seed infection was only $6.67 \%$ ) and enhanced the seed germination of brinjal [89]. Methanolic leaf extract of $L$. camara showed minimal inhibition of mycelial growth of A. flavus (17\%) at $10 \mathrm{mg} / \mathrm{ml}$ concentration but effective inhibition of aflatoxin B1 production $(72.36 \%)$ at $25 \mathrm{mg} / \mathrm{ml}$ concentration [90]. The antifungal activity of ethanol extract of $L$. camara was evaluated against 
Table 2: Antifungal activity of Lantana camara

\begin{tabular}{|c|c|c|}
\hline Sl. No. & Fungi (activity against) & References \\
\hline 1 & Alternaria alternata; Alternaria sp.; Alternaria solani & $31,35,43,88,92,94,96,97,99,100,101,106,108$ \\
\hline 2 & $\begin{array}{l}\text { Aspergillus niger; Aspergillus flavus; Aspergillus awamori; Aspergillus } \\
\text { parasiticus; Aspergillus sp.; Aspergillus fumigatus }\end{array}$ & $\begin{array}{l}31,35,43,44,49,52,56,73,81,83,85,88,89,90,93,96, \\
97,99,100\end{array}$ \\
\hline 3 & Botrytis cinerea & 106,108 \\
\hline 4 & $\begin{array}{l}\text { Candida albicans; Candida dubliniensis; Candida krusei; Candida } \\
\text { guilliermondii; Candida tropicalis; Candida parapsilosis; Candida glabrata }\end{array}$ & $3,31,37,38,45,56,57,59,69,73,91,100,102,107$ \\
\hline 5 & Cladosporium cucumerinum & 16 \\
\hline 6 & Colletotrichum gloeosporioides & $85,103,104$ \\
\hline 7 & Curvularia lunata & $31,89,97,100$ \\
\hline 8 & Drechslera biseptata & 35 \\
\hline 9 & Epidermophyton floccosum & 37,84 \\
\hline 10 & Fusarium oxysporum; Fusarium solani; Fusarium sp.; Fusarium moniliforme & $31,35,49,56,58,82,85,86,89,95,96,99,106$ \\
\hline 11 & Helminthosporium solani & 108 \\
\hline 12 & Humicola grisea & 108 \\
\hline 13 & Macrophomina phaseolina & 88 \\
\hline 14 & Malassezia furfur & 38 \\
\hline 15 & Microsporum canis; Microsporum gypseum & 37,84 \\
\hline 16 & Mucor sp.; Mucor hiemalis & 49,108 \\
\hline 17 & $\begin{array}{l}\text { Penicillium funiculosum; Penicillium janthinellum; Penicillium expansum; } \\
\text { Penicillium sp.; Penicillium digitatum }\end{array}$ & $58,85,89,98,99$ \\
\hline 18 & Phomopsis vexans & 89 \\
\hline 19 & Phytophthora nicotiana & 85 \\
\hline 20 & Pythium ultimum; Pythium aphanidermatum; Pythium sp. & $85,95,96,106$ \\
\hline 21 & Rhizoctonia solani; Rhizoctonia bataticola & $85,88,93,95,106$ \\
\hline 22 & Rhizomucor tauricus & 58 \\
\hline 23 & Rhizopus solani & 43 \\
\hline 24 & Saccharomyces cerevisiae & 31 \\
\hline 25 & Sclerotium rolfsii & 31,105 \\
\hline 26 & Trichoderma reesei; Trichoderma harzianum; Trichoderma sp. & $58,85,99$ \\
\hline 27 & $\begin{array}{l}\text { Trichophyton mentagrophytes; Trichophyton rubrum, Trichophyton } \\
\text { verrucosum; Trichophyton tonsurans; Trichophyton violaceum }\end{array}$ & $3,37,52,84,97,102$ \\
\hline 28 & Verticillium dahliae & 106 \\
\hline 29 & White and brown rot fungi (Trametes versicolor; Oligoporus placenta) & 87 \\
\hline
\end{tabular}

six species of Candida (C. albicans, Candida dubliniensis, Candida krusei, Candida guilliermondii, Candida tropicalis and Candida parapsilosis). Stem extract inhibited C. dubliniensis, C. albicans and C. guillermondii growth, while leaf extract inhibited $C$. krusei. Chromatographic studies revealed that the stem and leaves of $L$. camara contained flavonoids with antifungal effect [91]. Eleven fungal strains, C. albicans (MTCC 1022), C. tropicalis, Saccharomyces cerevisiae (MTCC 17322), A. niger, A. flavus, Penicillium sp., F. oxysporum, A. alternata, Sclerotium rolfsii, and $C$. lunata were used to test antifungal activity of $L$. camara ethanol and acetone extracts. The extracts were ineffective against Candida spp., tested and moderately effective against $S$. cerevisiae. All other fungal isolates tested exhibited maximum percentage growth inhibition at $1000 \mu \mathrm{g} / \mathrm{ml}$ concentration of both ethanolic and acetone extract. Acetone extract showed greater antifungal potential than the ethanolic extract [31]. L. camara was screened against Alternaria sp. which causes different plant diseases especially in vegetable plants. At $20 \mathrm{mg} / \mathrm{ml}$ dose L. camara exhibited significant antifungal activity against Alternaria sp. [92].

The antifungal activity of $L$. camara extracts was evaluated against A. niger, A. flavus, Rhizoctonia bataticola, and $R$. solani. L. camara exhibited moderate inhibition against all tested pathogens. Among the three solvents extracts highest inhibition of radial mycelial growth of all four pathogens was observed with ethanol extract, acetone extract showed moderate inhibition while minimum inhibition was recorded in water extract of the plant [93]. The efficacy of aqueous and chloroform extracts of L. camara against major seed-borne fungi A. niger, A. alternata, Drechslera biseptata, and F. solani were studied in vitro. Both extracts showed similar activities (moderate) against all the fungi tested [35]. C. albicans (ATCC 10231), C. tropicalis, C. parapsilosis (ATCC 22019), C. krusei and dermatophytic fungi T. rubrum (RSKK 486), E. floccosum (RSKK 3027), M. gypseum (NCPF 580) were used for antifungal activity. L. camara flower extracts showed better antifungal activity against
C. parapsilosis, C. albicans, C. krusei and C. tropicalis, with MIC values ranging between 8 and $32 \mu \mathrm{g} / \mathrm{ml}$. Significant antidermatophytic activity was also observed wherein MICs ranged between 16 and $64 \mu \mathrm{g} / \mathrm{ml}$ [37]. Petroleum ether and methanolic extracts of L. camara leaves were screened against C. albicans MTCC 227 and Malassezia furfur MTCC 1374. Both the solvent extracts showed good antifungal activity against the fungi tested [38]. The leaf extracts of L. camara in different organic solvents (methanol, acetone, ethanol and aqueous) were assessed in vitro for fungitoxic activity against phytopathogenic A. alternata isolated from potato (Solanum tuberosum) and tomato (Lycopersicon esculentum). Among the four extracts, ethanol and acetone extracts showed complete inhibition of growth of fungus; while methanol extract showed $50 \%$ inhibition and aqueous extract did not inhibit the fungus [94].

Methanolic extract from L. camara leaves was evaluated for its antifungal efficiency on tomato phytopathogenic fungi F. oxysporum, Pythium aphanidermatum, and $R$. solani. L. camara extract was very effective against $P$. aphanidermatum which was completely inhibited at $10 \mathrm{mg} / \mathrm{ml}$, while moderately effective against $F$. oxysporum and $R$. solani with $28 \%$ and $17 \%$ inhibition respectively at $10 \mathrm{mg} / \mathrm{ml}$ [95]. Hexane, ethylacetate and methanol extracts of leaf and stem bark of L. camara were screened against Aspergillus sp., Alternaria sp., Pythium sp. and Fusarium sp. Ethyl acetate extract of leaf showed antifungal activity against all the tested fungi after 48 h of incubation, while methanol extract against only Pythium sp. Ethyl acetate extract of stem bark inhibited growth of Aspergillus sp. and Alternaria sp., while methanol extract inhibited Alternaria sp. and Fusarium sp. after $48 \mathrm{hr}$ of incubation. Hexane extracts had no inhibitory effect on any fungi tested [96]. Antifungal activity of ethanol, methanol and petroleum ether extracts of $L$. camara leaves was studied against important allergenic and pathogenic fungi Trichophyton tonsurans, A. niger, A. alternata, and C. lunata. Effective inhibition of mycelia growth of all tested fungi was observed with ethanol and methanol extracts while petroleum ether extract showed good activity against $A$. alternata 
and $C$. lunata, and moderate activity against T. tonsurans and A. niger at $100 \mathrm{mg} / \mathrm{ml}$ concentration [97]. The antifungal activity of L. camara flower extracts (ethanol and methanol) against four pathogenic fungi: A. flavus, A. niger, A. alternata and R. solani was assessed by measuring MIC using the disc diffusion method. The results showed that all the extracts of L. camara flowers possessed notable antifungal activity against all the tested fungal strains [43]. Methanol, ethanol and water extracts of L. camara leaves were evaluated against two fungal strains (Aspergillus fumigatus and A. flavus). The methanol extract exhibited significant inhibition (71\%) and (66\%) against A. fumigatus and A. flavus, respectively [44]. In vitro antifungal activities of cold-ethanolic extracts of $L$. camara leaves were compared to the hot-ethanolic extracts of the same plant. The highest zone of inhibition was recorded against C. albicans $(29 \mathrm{~mm})$ with cold ethanolic extract. The cold extract was more effective compared to the hot extract [45]. Verbascoside purified from leaf extract of $L$. camara displayed effective in vivo inhibition of Penicillium digitatum on oranges [98]. Methanol extract of L. camara fruit was tested against three fungal strains Mucor sp., A. fumigatus and Fusarium moniliforme. The extract exhibited 40\%, 38\% and 48\% growth inhibition of tested fungi, respectively [49].

The ethyl acetate extract of $L$. camara stem bark was divided into two fractions (A and B) by the thin layer chromatography (TLC) analysis. The antifungal bioassay was done to the above two fractions against Aspergillus sp., Alternaria sp., Fusarium sp., Trichoderma sp., and Penicillium sp. Fraction B showed higher antifungal activity than fraction A against all tested fungi. The fraction $B$ was then divided into two fractions $\mathrm{X}$ and $\mathrm{Y}$ based on TLC analysis. The antifungal bioassay was also done to fractions $X$ and $Y$ against same fungi. Both fractions $X$ and $Y$ showed highest inhibition on Fusarium sp. with 25 and $32 \mathrm{~mm}$ and on Penicillium sp. with $26 \mathrm{~mm}$ and $34 \mathrm{~mm}$, respectively, after $48 \mathrm{hrs}$ of incubation. They also showed good antifungal activity against other tested fungi at $48 \mathrm{hr}$ of incubation except fraction $\mathrm{X}$ on Alternaria sp., where no activity was observed [99]. Aqueous extract of L. camara leaves showed significant antifungal activity against $A$. niger ATCC 16888 with maximum growth inhibition of $14 \pm 0.142 \mathrm{~mm}$ at $30 \mathrm{mg} / \mathrm{ml}$, while it was $37 \pm 0.124 \mathrm{~mm}$ for the standard antifungal agent vericonozole at $30 \mathrm{mg} /$ disc. The MIC of the extract was $18 \mathrm{mg} / \mathrm{ml}$ [81]. Antifungal activity of hexane extract of $L$. camara leaves was evaluated against $A$. niger and Trichophyton violaceum. The hexane extract showed activity only against $A$. niger in all the concentrations tested [52]. Methanol extract of $L$. camara leaves showed antifungal activity against A. alternata (NCIM 718), A. niger (MTCC 2202), C. albicans (ATCC 10231), C. lunata (NCIM 716). The MIC and minimal lethal concentration (MLC) values were A. alternata $(0.7$ and $0.9 \mathrm{mg} / \mathrm{ml})$, A. niger $(0.4$ and $0.9 \mathrm{mg} / \mathrm{ml})$, C. albicans $(0.3$ and $0.5 \mathrm{mg} / \mathrm{ml})$ and $C$. lunata $(0.8 \mathrm{mg} / \mathrm{ml})$. Least MIC and MLC was observed against $A$. niger and $C$. albicans [100]. Methanolic extracts of L. camara were screened in vitro for its antifungal activity against $A$. alternata at 5, 10 and 20\% concentrations. At 5\% concentration (50 mg/ml), up to $96 \mathrm{hrs}$, maximum mycelial growth inhibition $(100 \%)$ was observed by the extract of L. camara [101].

Evaluation of antifungal activities of the ethanolic, methanolic and aqueous extracts of $L$. camara against the two fungal organisms T. rubrum and $C$. albicans was carried out. The ethanolic extract showed the most inhibition potential against the two fungi followed by methanol extract at all the three 10\%, 20\% and 30\% concentrations tested [102]. L. camara extracts significantly reduced radial growth and conidia formation of $C$. gloeosporioides, and reduced anthracnose disease development on mango fruits. Thus, L. camara extracts could serve as an alternative means of post-harvest mango anthracnose disease management [103]. Ethanol leaf extract of L. camara possessed significant fungicidal effect on the radial growth of $C$. gloeosporioides causing post-harvest disease of papaya [104]. The antifungal activity of ethanolic and petroleum ether extracts of L. camara leaves and flowers were tested in vitro against phytopathogenic fungus $S$. rolfsii Sacc., using poison food method. Ethanolic extract of L. camara leaves showed $50 \%$ inhibition of the growth while the petroleum ether extracts of L. camara had no activity against $S$. rolfsii [105].
EOs

The EO of L. camara, tested against eight fungi, showed a wide spectrum of antifungal activities. Highest inhibition was seen for C. albicans, Aspergillus sp., and F. solani [56]. The EO of L. camara leaves exhibited considerable antifungal activity against $C$. albicans at $5 \mathrm{mg} / \mathrm{ml}$ concentration [57]. Volatile components extracted from the leaves, stems and flowers of L. camara were tested against Alternaria solani, Botrytis cinerea, F. solani f. sp. cucurbitae, F. oxysporum f. sp. niveum, P. ultimum, R. solani, and Verticillium dahliae. Volatile components extracted from the flowers of L. camara had the strongest antifungal effect (38\%), followed by components from the leaves $(27.1 \%)$ and stems (26.6\%). Complete inhibition was achieved against $V$. dahliae. The weakest effect was against P. ultimum [106]. L. camara oil was effective in inhibiting the growth of $A$. niger, and reducing the growth of other fungi (F. solani, Penicillium funiculosum, Rhizomucor tauricus, Trichoderma reesei) [58]. The EO showed moderate activity against C. albicans MTTC 227 [59]. Antifungal activity of EOLC leaves was studied against $C$. albicans and $C$. krusei ATCC 6258. The EO remarkably inhibited the growth of the fungi tested [107]. The EO of L. camara flowers exhibited antifungal activity against $C$. albicans and C. glabrata in all the concentrations tested [69]. The antifungal activity of EOLC was tested against five phyto-pathogenic fungi viz., A. alternata (MTCC 149), Mucor hiemalis (MTCC 157), Helminthosporium solani (MTCC 1899), Humicola grisea (MTCC 352), and B. cinerea (MTCC 359). The EOs exhibited antifungal activity against all the tested fungi till 32 days of incubation which was equivalent to the standard fluconazole [108].

\section{Nanoparticles}

Biosynthesized AgNPs from aqueous extract of L. camara leaves showed good antifungal activity against $C$. albicans and A. niger at 100, 200 and $300 \mu \mathrm{g} / \mathrm{ml}[73]$.

\section{Antiprotozoal activity}

The root bark extract of $L$. camara showed in vitro activity against Plasmodium falciparum causing malaria [109]. Braga et al. [110] confirmed the antileishmanial activity of methanolic extract of L. camara leaves against Leishmania amazonensis and L. chagasi. Jonville et al. [111] investigated antimalarial activity of dichloromethane and methanol extract of L. camara through in vitro studies against the 3D7 and W2 strain of P. falciparum and in vivo studies against Plasmodium berghei infected mice and reported effective in vitro activity of the dichloromethane leaves extract against $P$. falciparum and moderate in vivo activity against $P$. berghei. Dichloromethane was found to posses more potent activity. Good antiplasmodial activity was found in $L$. camara leaf ethyl acetate extract $\left(\mathrm{IC}_{50}=19 \mu \mathrm{g} / \mathrm{ml}\right.$ ) against the tested strains of $P$. falciparum [112]. The EO of L. camara showed antiplasmodial activity similar to that of chloroquine against the multi-drug-resistant strain of $P$. falciparum FCM29, but not the high activity as achieved by quinine [113]. Oleanolic acid, ursolic acid, lantadene A, and lantanilic acid obtained from the aerial parts of L. camara showed significant leishmanicidal activities against promastigotes of Leishmania major with $\mathrm{IC}_{50}$ values of 53.0, 12.4, 20.4, and $21.3 \mu \mathrm{M}$, respectively [114]. L. camara EO was very effective against L. amazonensis (IC50=0.25 $\mu \mathrm{g} / \mathrm{ml}$ ) and L. chagasi (IC $50=18 \mu \mathrm{g} / \mathrm{ml}$ ) [115]. The EO of L. camara inhibited Leishmania braziliensis and Trypanosoma cruzi with IC50 of 72.31 and $201.94 \mu \mathrm{g} / \mathrm{ml}$, respectively [116].

\section{Antinematode activity}

Leaf extracts of L. camara applied to Meloidogyne incognita killed all larvae up to $\mathrm{S}_{2}$ concentration within $5 \mathrm{hr}$. At $\mathrm{S}_{1} 0$ the mortality was $96.59 \%$ which increased to $100 \%, 30 \mathrm{hr}$ after treatment [117]. Lantanoside, linaroside, and camarinic acid isolated from the aerial parts of L. camara were tested for nematicidal activity against root-knot nematode $M$. incognita and showed $90 \%, 85 \%$, and $100 \%$ mortality, respectively, at $1.0 \%$ concentration. The results were comparable to those obtained with the conventional nematicide furadan $(100 \%$ mortality at $1.0 \%$ concentration) [118]. Aqueous, methanol, ethyl acetate, and hexane extracts of $L$. camara leaves caused significant 
mortality of Meloidogyne javanica juveniles in vitro. Aqueous and methanolic extracts demonstrated greater inhibition $193 \%$ and $78 \%$ mortality at $10 \mathrm{mg} / \mathrm{ml}$ ) compared to ethyl acetate or hexane extracts. Decomposing leaves of L. camara used alone or in combination with $P$. aeruginosa markedly suppressed population densities of $M$. javanica and subsequent root-knot development in mungbean [119]. Shaukat and Siddiqui [120] reported the nematicidal activity of L. camara against juveniles of M. javanica on mungbean. Concentrated and diluted root leachate of $L$. camara caused substantial mortality of $M$. javanica juveniles, the root-knot nematode. Application of the L. camara root leachates in combination with $P$. aeruginosa, a plant growth-promoting rhizobacterium, significantly reduced nematode population densities in roots and subsequent root-knot infection and enhanced plant growth [121]. Aqueous leaf extract of $L$. camara was very effective in complete inhibition of egg hatching and subsequent larval penetration of M. incognita in banana at 48, 96 and $144 \mathrm{hrs}$ indicating ovicidal effects [122]. Lantanilic acid, camaric acid, and oleanolic acid were isolated from methanolic extract of the aerial parts of L. camara and these compounds exhibited 98\%, 95\% and 70\% mortality; respectively, against root-knot nematode $M$. incognita at $0.5 \%$ concentration [123]. Begum et al. [124] isolated pomolic acid, lantanolic acid, lantoic acid, camarin, lantacin, camarinin, and ursolic acid from aerial part of L. camara and investigated their nematicidal activity against root-knot nematode $M$. incognita. Pomolic acid, lantanolic acid, and lantoic acid exhibited $100 \%$ mortality at $1 \mathrm{mg} / \mathrm{ml}$ concentration after $24 \mathrm{hr}$, while camarin, lantacin, camarinin, and ursolic acid produced similar effect after $48 \mathrm{hr}$ at same concentration.

Aqueous leaf extract of L. camara was assessed in vitro conditions against juveniles of $M$. incognita from eggplant. The standard concentration ' $\mathrm{S}$ ' of leaf extract was found to be highly nematostatic, where nematodes were completely paralyzed after $12 \mathrm{hr}$ and after $48 \mathrm{hr}$ of exposure, $96 \%$ of juveniles were killed at same concentration [125]. The nematicidal activity of the aqueous extract of L. camara flowers and leaves was tested against citrus nematode Tylenchulus semipenetrans in vitro and in vivo. In vitro the extract significantly caused juvenile mortality (96\% at $100 \%$ concentration and $93 \%$ at $50 \%$ ). In greenhouse experiment, the aqueous extract was effective against population density of juveniles, where the mortality was $78.7 \%$, reduction of nematode females was $74.5 \%$ and reduction of egg-masses was $70.0 \%$ [126]. The root-dip treatment of the standard concentration (S) of aqueous extract of L. camara leaves effectively inhibited larval penetration in roots of tomato. Mixing organic residue of both test plants with soil at $0.5 \%, 1.0 \%$ and $3.0 \%$ $(\mathrm{w} / \mathrm{w}) 5$ days before tomato transplanting, improved plant growth response and reduced root-knot development in roots at a 6 and $12 \%$ moisture levels [127]. The saponin of L. camara was effective against the migration of second stage larvae of eggplant nematode, Meloidogyne sp., with EC50 value of $4906.8 \mathrm{ppm}$, and percentage inhibition of root galling formation was $100 \%$ at 5000 ppm concentration [128]. Oleanonic acid isolated from the aerial parts of L. camara exhibited $80 \%$ mortality against $M$. incognita after $72 \mathrm{hr}$ at $0.0625 \%$ concentration, which is comparable with that of the standard furadan [129]. Aqueous leaf extract of L. camara was assessed against juveniles of Meloidogyne sp. for its nematicidal potency in vitro. $50 \%$ concentration of leaf extract at $48 \mathrm{hr}$ of incubation period and above showed effective immobilization of Meloidogyne sp., larvae and $57.66 \%$ of nematode juveniles were found dead in $48 \mathrm{hr}$. Similarly, the $100 \%$ leaf extract was highly nematostatic and $98.66 \%$ of nematode juveniles were found dead in $48 \mathrm{hr}$ [130].

\section{Antiviral activity}

Antiviral substances were extracted from L. camara with petroleum ether, benzene, diethyl ether, chloroform, ethyl acetate, methanol, ethanol, and distilled water separately. Each extract was tested for its activity against white spot syndrome virus (WSSV) in marine shrimp and fresh water crabs. Aqueous extract of L. camara showed partial antiviral activity against WSSV ( $40 \%$ mortality at $150 \mathrm{mg} / \mathrm{kg}$ of animal body weight) [131]. The aqueous extract from L. camara was screened for antiviral activities using cytopathic effect reduction assay, which showed antiviral activity against WSSV [132]. L. camara root extract was used to treat cell culture challenged with virus, polio virus Type I. The result indicated that the extract offered slight protection when the cells were treated with $100-200 \mu \mathrm{g} / \mathrm{ml}$ of the extract [133]. Cell culture challenged with polio virus Type I was treated with L. camara leaves extract. The result indicated that the plant leaves extract offered better protection when the cells were treated with $100 \mu \mathrm{g} / \mathrm{ml}$ of the extract [134]

\section{CONCLUSION}

The information about natural healing methods has been passed from one generation to another. With growing knowledge on technology and civilization this information transfer is no longer taken seriously in the society, hence, endangering the knowledge of traditional methods of treatment, one of them is the use of medicinal plants. This calls for a great need to have the knowledge on medicinal plants documented and kept for future reference [135]. India has a rich tradition of plant based knowledge in health care. Among the large number of herbal drugs existing in India, very few have been studied systematically so far. L. camara is an evergreen plant found throughout India. Traditionally, it has been used in treating various ailments and they are supported by scientific data. However, most of the pharmacological studies were preliminary and requires intensive preclinical and clinical studies to evaluate the efficacy and toxicity of these plant products.

\section{REFERENCES}

1. Ashwini S, Girish K. Phytochemical screening and antibacterial activity of methanolic leaf extract of Coleus aromaticus Benth. Int $\mathrm{J}$ Res Pharm Sci 2014;5(4):270-4

2. Swamy MK, Sinniah UR, Akhtar MS. In vitro pharmacological activities and GC-MS analysis of different solvent extracts of Lantana camara leaves collected from tropical region of Malaysia. Evid Based Complement Alternat Med 2015;2015:506413.

3. Sharma B, Kumar P. Bioefficacy of Lantana camara L. Against Some Human Pathogens. Indian J Pharm Sci 2009;71(5):589-93.

4. Srinivasahan V, Durairaj B. Antioxidant and free radical scavenging effect of Morinda citrifolia fruit extract. Int J Pharm Pharm Sci 2014;6(4):55-9.

5. Girish K. Antimicrobial activities of Coleus aromaticus Benth. J Pharm Res 2016;10(10):635-46.

6. Santos PR, Oliveira AC, Tomassini TC. Controle microbiogico de productous fitoterapicos. Rev Farm Bioquim 1995;31:35-8.

7. Ross IA. Medicinal Plants of the World: Chemical Constituents, Traditional and Modern Medicinal Uses. $2^{\text {nd }}$ ed. Totowa, NJ: Humana Press Inc.; 2001. p. 289-90.

8. Ghisalberti EL. Lantana camara L. (Verbenaceae). Fitoterapia 2000;71:467-86

9. Lonare MK, Sharma M, Hajare SW, Borekar VI. Lantana camara: Overview on toxic to potent medicinal properties. Int J Pharm Sci Res 2012;3(9):3031-5.

10. Sharma P, Shrivastava B, Sharma GN, Jadhav HR. Phytochemical and pharmacological profile of Lanata camara: An overview. J Adv Pharm Educ Res 2013;3(4):294-305.

11. Samy RP, Pushparaj PN, Gopalakrishnakone P. A compilation of bioactive compounds from Ayurveda. Bioinformation 2008;3(3):100-10

12. Patel S. A weed with multiple utility: Lantana camara. Rev Environ Sci Biotechnol 2011;10(4):341-51.

13. Ganjewala D, Sam S, Khan KH. Biochemical compositions and antibactericidal activities of Lantana camara plants with yellow, lavender and white flower. Eur Asian J Biosci 2009;3(10):69-77.

14. Priya K, Ganjewala D. Antibacterial activities and phytochemical analysis of different plant parts of Nyctanthes arbor-tristis L. Res J Phytochem 2007;1:61-7.

15. Sousa EO, Almedia TS, Menez IR, Rodriguez FF, Campos AR, Lima SG, et al. Chemical composition of essential oils of Lantana camara L. (Verbenacea) and synergistic effect of aminoglycosides gentamicin and amikacin. Rec Nat Prod 2012;6(2):144-50.

16. Alves TM, Silva AF, Brandão M, Grandi TS, Smânia E, Smânia Júnior A, et al. Biological screening of Brazilian medicinal plants. Mem Inst Oswaldo Cruz 2000;95:367-73.

17. Sukul S, Chaudhuri S. Antibacterial natural products from leaves of Lantana camara L. Indian J Pharm Sci 2001;63:20-3. 
18. Basu S, Ghosh A, Hazra B. Evaluation of the antibacterial activity of Ventilago madraspatana Gaertn. Rubia cordifolia Linn. and Lantana camara Linn: Isolation of emodin and physcion as active antibacterial agents. Phytother Res 2005;19(10):888-94

19. Kumar VP, Chauhan NS, Padh H, Rajani M. Search for antibacterial and antifungal agents from selected Indian medicinal plants. J Ethnopharmacol 2006;107(2):182-8.

20. Begum S, Wahab A, Siddiqui BS. Antimycobacterial activity of flavonoids from Lantana camara Linn. Nat Prod Res 2008;22(6):467-70.

21. Badakhshan MP, Sasidharan S, Rameshwar NJ, Ramanathan S. A comparative study: Antimicrobial activity of methanol extracts of Lantana camara various parts. Pharmacogn Res 2009;1(6):348-51.

22. Kirimuhuzya C, Waako P, Joloba M, Odyek O. The anti-mycobacterial activity of Lantana camara a plant traditionally used to treat symptoms of tuberculosis in South-Western Uganda. Afr Health Sci 2009;9(1):40-5.

23. Vaidya GS, Bhattarai N. Antagonistic study of Lantana camara (Linn) against with pathogenic bacteria. Sci World 2009;7(7):64-7.

24. Barreto F, Sousa E, Campos A, Costa J, Rodrigues F. Antibacterial activity of Lantana camara Linn and Lantana montevidensis brig extracts from cariri-ceará, Brazil. J Young Pharm 2010;2(1):42-4.

25. Gupta RN, Viswas K, Pathak M, Singh PS, Gupta A. Antibacterial activities of ethanolic extracts of plants used in folk medicine. Int J Res Ayurveda Pharm 2010;1(2):529-35.

26. Mani LM, Sankar C, Dilip C, Azeem AK, Raj D, Mathew L, et al. Antimicrobial studies on extracts of Lantana camara. Linn. Der Pharm Lett 2010;2(5):80-2.

27. Vardhana SH. Antibacterial activity of root of Lantana camera Linn. Pharmacol Online 2011;2:1427-30.

28. Kalyani L, Rao AL, Mishra US. Antibacterial and analgesic activity of leaves of Lantana camara. Int J Phytomed 2011;3:381-5.

29. Mary KV. Studies on phytochemical screening and antibacterial activities of Lantana camara Linn. Plant Sci Feed 2011;1(5):74-9.

30. Mohapatra TK, Dash V, Behera SK, Parida B, Sahoo AM, Nayak RR, et al. Evaluation of anthelmintic and antimicrobial activity of the leaves of Lantana camara. Int Res J Pharm Sci 2011;2(1):10-3

31. Saraf A, Quereshi S, Sharma K, Khan NA. Antimicrobial activity of Lantana camara L. J. Exp Sci 2011;2(10):50-4.

32. Sathish R, Vyawahare B, Natarajan K. Antiulcerogenic activity of Lantana camara leaves on gastric and duodenal ulcers in experimental rats. J Ethnopharmacol 2011;134(1):195-7.

33. Agrawal MK, Varma A, Goyal S. Antibacterial screening of extract of the leaves of Lantana camara. Indian J Life Sci 2012;1(2):97-9.

34. Bangou MJ, Almaraz-Abarca N, Méda NT, Zeba B, Kiendrebéogo M, Millogo-Rasolodimby J, et al. Polyphenolic composition of Lantana camara and Lippia chevalieri, and their antioxidant and antimicrobial activities. Int J Phytomed 2012;4:115-24.

35. Mushatq S, Haider MS, Ali A, Javed S, Khokhar I, Mukhtar I. In vitro comparative screening of antibacterial and antifungal activities of some common weeds extracts. Pak J Weed Sci Res 2012;18(1):15-25.

36. Nagumanthri V, Rahiman S, Tantry BA, Nissankararao P, Kumar MP. In vitro Antimicrobial activity of Acacia nilotica, Ziziphus mauritiana, Bauhinia variegate and Lantana camara against some clinical isolated strains. Iran J Sci Technol 2012;A2:213-17.

37. Orhan DD, Ozcelik B, Hoşbaş S, Vural M. Assessment of antioxidant, antibacterial, antimycobacterial, and antifungal activities of some plants used as folk remedies in Turkey against dermatophytes and yeast-like fungi. Turk J Biol 2012;36:672-86.

38. Pradhan RR, Kumar HD, Saswati S. Pharmacognostical, phytochemical and antimicrobial studies on the leaves of Lantana camara Linn. Der Pharm Lett 2012;4(6):1648-56.

39. Wadhai VS. Antibacterial activity of and comparative phytochemicals analysis of flower and leaves of Lantana camara. Bionano Front 2012;5(2-III):143-5.

40. Yasmeen R, Hashmi AS, Anjum AA, Saeed S, Muhammad K. Antibacterial activity of indigenous herbal extracts against urease producing bacteria. J Anim Plant Sci 2012;22(2):416-9.

41. Ashwini S, Anisa SK, Girish K. Phytochemical screening and antibacterial activity of methanolic leaf extracts of Lantana camara L. JSSCM J 2013;2:15-9.

42. Manzoor M, Anwar F, Sultana B, Mushtaq M. Variation in antioxidant and antimicrobial activities in Lantana camara L. Flowers in relation to extraction methods. Acta Sci Pol Technol Aliment 2013;12(3):283-94.

43. Naz R, Bano A. Phytochemical screening, antioxidants and antimicrobial potential of Lantana camara in different solvents. Asian Pac J Trop Dis 2013;3(6):480-6.
44. Obinna O, John A, Peter OO. The effect of extraction protocol on the phytochemical and antimicrobial activities of Lantana camara leaf extract found within a local environment. J Basic Appl Chem 2013;3(1):5-10.

45. Pawar K, Khetmalas S, Motkar B, Bande R, Wable H. Antimicrobial activity of Lantana camara (L) Var. Aculeata (L) Mold. (Verbanaceae). Indo Am J Pharm Res 2013;3(4):3284-94.

46. Pradeep BV, Tejaswini M, Nishal P, Pardhu G, Shylaja S, Kumar KC. Phytochemical screening and antimicrobial activities of plant extract of Lantana camara. J Environ Biol 2013;34(3):645-9.

47. Remya M, Vashum N, Sivasankar S. Bioactivity studies on Lantana camara Linn. Int J Pharm Bio Sci 2013;4(1):81-90.

48. Rizvi ZF, Mukhtar R, Chaudhary MF, Zia M. Antibacterial and antifungal activities of Lawsonia inermis, Lantana camara and Swertia angustifolia. Pak J Bot 2013;45(1):275-8.

49. Amutha S. Phytochemical investigation and in vitro evaluation of Lantana camara seed extracts on selected human pathogenic bacteria. Int J Pharm Bio Sci 2014;5(4):416-21.

50. Inbaraj SD, Menezes G, Josephine IG, Muniappan M, Muthiah NS. Antibacterial effect of Lantana camara Linn. On gram negative bacteria and NDM-1 strain: An in vitro study. Asian J Pharm Clin Res 2014;7(2):9-12.

51. Mariajancyrani, Chandramohan, Ravikumar. Terpenes and antimicrobial activity from Lantana camara leaves. Res J Recent Sci 2014;3(9):52-5.

52. Prakash NK, Bhuvaneswari S, Sripriya N, Arulmozhi R, Kavitha K, Aravitha R, et al. Studies on phytochemistry, antioxidant, antibacterial, larvicidal and pesticidal activities of aromatic plants from Yelagiri hills. Int J Pharm Pharm Sci 2014;6(5):325-8.

53. Sousa EO, Rodrigues FF, Campos AR, da Costa JG. Phytochemical analysis and modulation in aminoglycosides antibiotics activity by Lantana camara L. Acta Sci Biol Sci 2015;37(2):213-8.

54. Jhariya S. Antibacterial activity of root bark of Lantana camara. Int J Chem Pharm Anal 2016;3(3). Available from: http://www.pmindexing. com/journals/index.php/IJCPA/article/view/1012.

55. Jhariya S, Kakkar A. Evaluation of antibacterial activity of successive extract of Lantana camara flower. J Pharm Res 2016;10(8):534-6.

56. Deena MJ, Thoppil JE. Antimicrobial activity of the essential oil of Lantana camara. Fitoterapia 2000;71(4):453-5.

57. Kasali AA, Ekundayo O, Oyedeji AO, Adeniyi BA, Adeolu EO. Antimicrobial activity of the essential oil of Lantana camara (L.) Leaves. J Essent Oil Bear Plant 2002;5:108-10.

58. Dharmagada VS, Tandonb M, Vasudevan P. Biocidal activity of the essential oils of Lantana camara, Ocimum sanctum and Tagetes patula. J Sci Ind Res 2005;64:53-6.

59. Sonibare OO, Effiong I. Antibacterial activity and cytotoxicity of essential oil of Lantana camara L. Leaves from Nigeria. Afr J Biotechnol 2008;7(15):2618-20.

60. Costa JG, Sousa EO, Rodrigues FF, Lima SG, Braz-Filho R. Chemical composition, evaluation of antibacterial activity and toxicity of the essential oils from Lantana camara L. and Lantana sp. Braz J Pharmacogn 2009; 19:721-5.

61. Kurade NP, Jaitak V, Kaul VK, Sharma OP. Chemical composition and antibacterial activity of essential oils of Lantana camara, Ageratum houstonianum and Eupatorium adenophorum. Pharm Biol 2010;48(5):539-44.

62. Pattnaik S, Pattnaik B. A study of Lantana camara Linn. Aromatic oil as an antibacterial agent. Int Res J Pharm Sci 2010;1:32-5.

63. Sousa EO, Silva NF, Rodrigues FF, Campos AR, Lima SG, Costa JG. Chemical composition and resistance-modifying effect of the essential oil of Lantana camara Linn. Pharmacogn Mag 2010;6(22):79-82.

64. Dubey M, Sharma S, Sengar R, Bhadauria S, Gautam RK. In vitro antibacterial activity of Lantana camara leaves hydrosol. J Pharm Res 2011;4(11):3972-4

65. Montanari RM, Barbosa LC, Silva AJ, Andrade LS. Chemical composition and antibacterial activity of essential oils from Verbenaceae species: Alternative sources of (E)-caryophyllene and germacrene-D. Quim Nova 2011;34(9):1550-5.

66. Saikai AK, Sahoo RK. Chemical composition and antibacterial activity of essential oil of Lantana camara L. Middle-East J Sci Res 2011;8(3):599-602.

67. Elansary HO, Salem MZ, Ashmawy NA, Yacout MM. Chemical composition, antibacterial and antioxidant activities of leaves essential oils from Syzygium cumini L., Cupressus sempervirens L. And Lantana camara L. from Egypt. J Agric Sci 2012;4(10):144-52.

68. El Baroty GS, Goda HM, Khalifa EA, El Baky HH. Antimicrobial and antioxidant activities of leaves and flowers essential oils of Egyptian 
Lantana camara L. Der Pharm Chem 2014;6(6):246-55.

69. Filho AA, Santos RC, Filho WB, Ferraz VP, Takahashi JA. Antibacterial and antifungal activity of essential oil of flowers of Lantana camara in Roraima, Brazil. Planta Med 2014;80(LP65). DOI: 10.1055/s-0034-1395103.

70. Machado RR, Dutra RC, Pittella F, Raposo NR, Lesche B, Duarte RS, et al. Screening antimycobacterial activity of Baccharis dracunculifolia, Centella asiatica, Lantana camara and Pterodon emarginatus. Rev Braz Plant Med Camp 2015;17(4):891-9.

71. Salada JT, Balala LM, Vasquez EA. Phytochemical and antibacterial studies of Lantana camara L. Leaf fraction and essential oil. Int J Sci Res Publ 2015;5(3):1-5.

72. Sivakumar P, Nethradevi C, Renganathan S. Synthesis of silver nanoparticles using Lantana camara fruit extract and its effect on pathogens. Asian J Pharm Clin Res 2012;5(3):97-101.

73. Kumarasamyraja D, Jeganathan NS. Antimicrobial activity of bio synthesis silver nanoparticles prepared from the leaf extract of Lantana camara. Int Res J Pharm 2013;4(5):203-7.

74. Devi PR, Thilaga RD, Lakshmanan G, Babu C. Synthesis of silver nanoparticles from some selective plant seeds. Int J Res Pharm Sci 2014;5(3):30-2.

75. Verma V, Balasubramanian K. Experimental and theoretical investigations of Lantana camara oil diffusion from polyacrylonitrile membrane for pulsatile drug delivery system. Mater Sci Eng C Mater Biol Appl 2014;41:292-300.

76. Ajitha B, Ashok Kumar Reddy Y, Shameer S, Rajesh KM, Suneetha Y, Sreedhara Reddy P. Lantana camara leaf extract mediated silver nanoparticles: Antibacterial, green catalyst. J Photochem Photobiol B 2015;149:84-92.

77. Kumari A, Guliani A, Singla R, Yadav R, Yadav SK. Silver nanoparticles synthesised using plant extracts show strong antibacterial activity. IET Nanobiotechnol 2015;9(3):142-52.

78. Neeraja C, Begum SF, Rajesh G. Preparation of composites and evaluation of antibacterial efficacy. Int $\mathrm{J}$ Curr Adv Res 2015;4(11):478-81.

79. Devi PR, Lakshmanan G, Thilaga RD. Antimicrobial active silver nano particle synthesis from Lantana camara seed extract. Int J Pharm Res Dev 2015;7(5):39-43.

80. Singh PK, Bhardwaj K, Dubey P, Prabhune A. UV-assisted size sampling and sntibacterial screening of Lantana camara leaf extract synthesized silver nanoparticles. RSC Adv 2015;5:24513-20.

81. Nisha HB, Iswarya S, Kavitha V, Mandal AB, Gnanamani A. AntiAspergillus activity of Lantana camara Linn. Int J Pharm Sci Res 2014;5(10):4320-4.

82. Tripathi AK, Shukla BN. Antifungal activity of some plant extracts against Fusarium oxysporum sp. Causing wilt of linseed. J Mycol Plant Pathol 2002;32:266-7.

83. Patel SJ, Venugopalan N, Pradeep S. Screening for antimicrobial activity of weeds. Internet J Microbiol 2007;4(1). Available from: http://www.ispub.com/IJMB/4/1/3588.

84. Bokhari FM. Antifungal activity of some medicinal plants used in Jeddah, Saudi Arabia. Mycopath 2009;7(1):51-7

85. Mdee LK, Masoko P, Eloff JN. The activity of extracts of seven common invasive plant species on fungal phytopathogens. South Afr J Bot 2009;75:375-9.

86. Sharma B, Kumar P. In vitro antifungal potency of some plant extract against Fusarium oxysporum. Int J Green Pharm 2009;3(1):63-5.

87. Tripathi S, Rawat K, Swati D, Himani P. Potential of Lantana camara Linn. Weed against wood destroying fungi. Indian Forest 2009;135(3):403-11.

88. Vadlapudi V, Naidu CK. In vitro bioactivity of Indian medicinal plants Lantana camara and Mimosa pudica against important pathogens. Ann Biol Res 2010;1(1):98-101.

89. Kuri SK, Islam MR, Mondal U. Antifungal potentiality of some botanical extracts against important seedborne fungal pathogen associated with brinjal seeds, Solanum melongena L. J Agric Technol 2011;7(4):1139-53

90. Mostafa AA, Al-Rahmah AN, Abdel-Megeed A. Evaluation of some plant extracts for their antifungal and antiaflatoxigenic activities. J Med Plant Res 2011;5(17):4231-8.

91. Pardo AK, Arenas JJ, Gómez M, Lora FM, Gómez JE. Determination of antifungal activity of extracts of Lantana camara against Candida spp. Infect 2011;15(4):235-42.

92. Srivastava D, Singh P. Antifungal potential of two common weeds against plant pathogenic fungi-Alternaria sps. Asian J Exp Biol Sci 2011;2(3):525-8.

93. Gujar J, Talwankar D. Antifungal potential of crude plant extract on some pathogenic fungi. World J Sci Technol 2012;2:58-62.

94. Singh P, Srivastava D. Biofungicidal or biocontrol activity of Lantana camara against phytopathogenic Alternaria alternata. Int J Pharm Sci Res 2012;3(12):4818-21.

95. Al-Rahmah AN, Mostafa AA, Abdel-Megeed A, Yakout SM, Hussein SA. Fungicidal activities of certain methanolic plant extracts against tomato phytopathogenic fungi. Afr J Microbiol Res 2013;7(6):517-24.

96. Jeyasakthy S, Jeyadevan JP, Thavaranjit AC, Manoranjan T, Srikaran R, Krishnapillai N. Antifungal activity and qualitative phytochemical analysis of extracts obtained by sequential extraction of some medicinal plants in Jaffna Peninsula. Arch Appli Sci Res 2013;5(6):214-21.

97. Mandloi S, Varughese B, Mishra R, Varma R, Khan SS. Antifungal efficacy of Lantana camara L. Leaf extracts against some fungi. Nanobiotech Univ 2013;4:13-9.

98. Oyourou JN, Combrinck S, Regnier T, Marston A. Purification, stability and antifungal activity of verbascoside from Lippia javanica and Lantana camara leaf extracts. Ind Crops Prod 2013;43:820-6.

99. Gobika A, Jeyadevan JP, Thavaranjit AC, Manoranjan T. Investigation of Antifungal Properties of Lantana camara Stem Bark Extract and its Bioassay Guided Fractionation Proceedings of Jaffna University International Research Conference (JUICE 2014); University of Jaffna; 2014. p. 365-9.

100. Sailaja I. Antifungal activity of some wild plant extracts against fungal pathogens. Int J Integr Med Sci 2014;1(2):41-4.

101. Singh G, Gupta S, Sharma N. In vitro screening of selected plant extracts against Alternaria alternate. J Exp Biol Agric Sci 2014;2(3):344-51

102. Das L, Godbole S. Antifungal and phytochemical analysis of Lantana Camara, Citrus Limonum (Lemon), Azadirachta Indica (Neem) and Hibiscus rosasinensis (China Rose). J Pharm Res 2015;9(7):476-9.

103. Deressa T, Lemessa F, Wakjira M. Antifungal activity of some invasive alien plant leaf extracts against mango (Mangifera indica) anthracnose caused by Colletotrichum gloeosporioides. Int J Pest Manag 2015;61(2). Available from: http://www.dx.doi.org/10.1080/0 9670874.2015.1016135.

104. Prasad RR, Anamika A. Effects of plant leaf extract against Colletotrichum gloeosporioides (Penz) Sac. Causing post-harvest disease of papaya. J Agric Sci 2015;7(5):195-8.

105. Prabha S, Bapat UC, Kumar J. Antifungal activity of ethanolic and petroleum ether extracts of some medicinal plants against the plant pathogenic fungus Sclerotium rolfsii Sacc. Int J Bioassays 2016;5(7):4714-9

106. Boughalleb N, Débbabi N, Jannet HB, Mighri Z, El Mahjoub M. Antifungal activity of volatile components extracted from leaves, stems and flowers of four plants growing in Tunisia. Phytopathol Mediterr 2005;44:307-12.

107. Medeiros LB, Rocha MS, Lima SG, Sousa GR Jr, Citó AM, Silva D, et al. Chemical constituents and evaluation of cytotoxic and antifungal activity of Lantana camara essential oils. Braz J Pharmacogn 2012;22(6):1259-67.

108. Sharma D, Yami H, Sharma D, Shukla AK. Antifungal activities of essential oils from four commonly used ethno-medicinal plants. Asian J Ethnopharmacol Med Foods 2015;1(1):25-31.

109. Weenen H, Nkunya MH, Bray DH, Mwasumbi LB, Kinabo LS, Kilimali VA. Antimalarial activity of Tanzanian medicinal plants. Planta Med 1990;56(4):368-70.

110. Braga FG, Bouzada ML, Fabri RL, de O Matos M, Moreira FO, Scio E, et al. Antileishmanial and antifungal activity of plants used in traditional medicine in Brazil. J Ethnopharmacol 2007;111(2):396-402.

111. Jonville MC, Kodja H, Humeau L, Fournel J, De Mol P, Cao M, et al. Screening of medicinal plants from Reunion Island for antimalarial and cytotoxic activity. J Ethnopharmacol 2008;120(3):382-6

112. Kamaraj C, Kaushik NK, Rahuman AA, Mohanakrishnan D, Bagavan A, Elango G, et al. Antimalarial activities of medicinal plants traditionally used in the villages of Dharmapuri regions of South India. J Ethnopharmacol 2012;141(3):796-802.

113. Ratsimbason M, Ranarivelo L, Juliani HR, Simon JE. Antiplasmodial activity of twenty essential oils from Malagasy aromatic plants. In: Juliani HR, Simon JE, Ho CT, editors. African Natural Plant Products: New Discoveries and Challenges in Chemistry and Quality. Washington, DC: American Chemical Society; 2009. p. 209-15

114. Begum S, Ayub A, Qamar Zehra S, Shaheen Siddiqui B, Iqbal Choudhary M, Samreen. Leishmanicidal triterpenes from Lantana camara. Chem Biodivers 2014;11(5):709-18.

115. Machado RR, Júnior WV, Lesche B, Coimbra ES, de Souza NB, Abramo C, et al. Essential oil from leaves of Lantana camara: 
A potential source of medicine against leishmaniasis. Braz J Pharmacogn 2012;22(5):1011-7.

116. Barros LM, Duarte AE, Morais-Braga MF, Waczuk EP, Vega C, Leite NF, et al. Chemical Characterization and Trypanocidal, Leishmanicidal and Cytotoxicity Potential of Lantana camara L. (Verbenaceae) Essential Oil. Molecules 2016;21(2). pii:E209.

117. Chandel YS, Mehta PK. Nematicidal properties of leaf extract of wild sage (Lantana camara). Indian J Agric Sci 1990;60(11):781.

118. Begum S, Wahab A, Siddiqui BS, Qamar F. Nematicidal constituents of the aerial parts of Lantana camara. J Nat Prod 2000;63(6):765-7.

119. Ali NI, Siddiqui A, Zaki MJ, Shaukat SS. Nematicidal potential of Lantana camara against Meloidogyne javanica in mungbean. Nematol Mediterr 2001;29:99-102.

120. Shaukat S, Siddiqui I. Lantana camara in the soil changes the fungal community structure and reduces impact of Meloidogyne javanica on Mung bean. Phytopathol Mediterr 2001;40:245-52.

121. Shaukat SS, Siddiqui IA, Ali NI, Ali SA, Khan GH. Nematicidal and allelopathic responses of Lantana camara root extract. Phytopathol Mediterr 2003;42:71-8.

122. Patel AD, Patel DJ, Patel NB. Effect of aqueous leaf extracts of botanicals on egg hatching and larval penetration of Meloidogyne incognita in banana. Indian J Nematol 2004;34:37-9.

123. Qamar F, Begum S, Raza SM, Wahab A, Siddiqui BS. Nematicidal natural products from the aerial parts of Lantana camara Linn. Nat Prod Res 2005;19(6):609-13.

124. Begum S, Zehra SQ, Siddiqui BS, Fayyaz S, Ramzan M. Pentacyclic triterpenoids from the aerial parts of Lantana camara and their nematicidal activity. Chem Biodivers 2008;5:1856-66.

125. Ahmad F, Rather MA, Siddiqui MA. Nematicidal activity of leaf extracts from Lantana camara L. Against Meloidogyne incognita (Kofoid and White) Chitwood and its use to manage roots infection of Solanum melongena L. Braz Arch Biol Technol 2010;53(3):543-8.

126. Montasser SA, Abd-El-Wahab AE, Abd-Elgawad MM,
Abd-El-Khair H, Koura FF, Hammam MM. Role of some plant extracts and organic manure in controlling Tylenchulus semipenetrans Cobb in vitro and in vivo in citrus. J Appl Sci Res 2012;8(11):5415-24.

127. Ahmad F, Siddiqui MA, Babalola OO. Characterization of nematicidal activity of plant residues and their application with moisture approach against Meloidogyne incognita in tomato. Afr J Agric Res 2013;8(1):93-101.

128. Ibrahim HS, Hamouda SE, El-Kady AM, Abd-Alla HI. Study the nematicidal efficiency of Corchorus olitorius, Cinnamomum camphora, Portulace oleraceae and Lantana camara extracted saponins and their formulations on root-knot nematodes Meloidogyne spp. Nat Sci 2014;12(11):40-5.

129. Begum S, Ayub A, Siddiqui BS, Fayyaz S, Kazi F. Nematicidal triterpenoids from Lantana camara. Chem Biodivers 2015;12:1435-42.

130. Ghimire G, Gupta R, Keshari AK. Nematicidal activity of Lantana Camara L. For control of root-knot nematodes. Nepalese J Zool 2015;3(1):1-5.

131. Balasubramanian G, Sarathi M, Kumar RS, Hameed SA. Screening the antiviral activity of Indian medicinal plants against white spot syndrome virus in shrimp. Aquaculture 2007;263:15-9.

132. Das S. Exploitation of antiviral activity of traditionally used medicinal plants. J Antivir Antiretrovir 2011;3. Available from: http://www. dx.doi.org/10.4172/1948-5964.S1.15

133. Kanagavalli R, Kumar MS, Vijayan P, Kumar MR, Kavitha K. In vitro studies on the antiviral property of Lantana camara root. Invent 2011. Available from: http://www.inventi.in/journal/article/impact/64/1019/ pharm-biotech-microbio/pi.

134. Kanagavalli R, Kumar MS, Kumar MR, Kavitha K, Singh SD. In vitro studies on the antiviral property of Lantana Camara leaves extract. Asian J Biochem Pharm Res 2011;4(1):135-41.

135. Akumu EO, Anthoney ST, Ngule CM, Jackei KO, Miyogo E. Phytopharmacological evaluation of Lantana camara leaves smoke. Int J Pharm Bio Sci 2014;4(2):28-34. 